\title{
Gender-specific association of vitamin D receptor polymorphism combinations with type 1 diabetes mellitus
}

\author{
Balázs Györffy, Barna Vásárhelyi ${ }^{1}$, Dóra Krikovszky, László Madácsy, Attila Tordai ${ }^{2}$ Tivadar Tulassay and \\ András Szabó \\ First Department of Paediatrics, Semmelweis University, Budapest, Hungary, ${ }^{1}$ Research Laboratory for Paediatrics and Nephrology, Hungarian Academy \\ of Sciences and Semmelweis University, Budapest, Hungary and ${ }^{2}$ National Medical Centre, Institute of Haematology and Immunology, Budapest, \\ Hungary \\ (Correspondence should be addressed to B Györffy, Bokay u. 53, Budapest, H-1083, Hungary; Email: 3414698@westel900.net)
}

\begin{abstract}
Objective: Recent data have indicated the significance of vitamin D receptor (VDR) polymorphisms in type 1 diabetes mellitus (T1DM). We have studied the association of five known restriction enzyme polymorphisms of the VDR gene in patients with T1DM.

Design and Methods: One hundred and seven children with T1DM (T1DM for 5 years; age, 1-14 years; boys/girls, 57/50; body mass index, $17.0 \pm 2.3 \mathrm{~kg} / \mathrm{m}^{2}$; haemoglobin $\left.\mathrm{A}_{\mathrm{Ic}}\left(\mathrm{Hb}_{\mathrm{Ic}}\right), 7.87 \pm 1.05\right)$ and 103 healthy subjects were enrolled. The VDR polymorphisms ApaI, BsmI, FokI, TaqI and Tru9I ('a', 'b', 'f', 't' and 'u' alleles respectively) were investigated.

Results: The 't' and ' $\mathrm{T}$ ' alleles miss the Hardy-Weinberg equilibrium $(P<0.01)$ in control and diabetic populations; we therefore excluded this polymorphism from further analysis. We did not find a difference in the allele prevalence in T1DM patients and controls of any of the five polymorphisms. However, when the ' $b$ ', 'a' and ' $u$ ' alleles were simultaneously compared in girls, there was a significantly higher prevalence in patients with diabetes compared with controls ('b' + 'a' + 'u' present/absent: healthy, 0/53; diabetic, 13/37; $P<0.005)$. In boys the prevalence of ' $b$ ' + ' $a$ ' + 'u' genotype was similar in T1DM and controls.

Conclusions: The impact of the ' $t$ ' allele cannot be investigated in this study population. Not a single VDR polymorphism increases the susceptibility to T1DM. The common presence of the 'b', 'a' and ' $u$ ' alleles greatly increases the probability of T1DM in girls.
\end{abstract}

European Journal of Endocrinology 147 803-808

\section{Introduction}

Dietary vitamin D supplementation has recently been associated with reduced risk of type 1 diabetes (T1DM) in a large-scale study (1). In vitro vitamin D acts as an immunosuppressive agent. It reduces lymphocyte activation, proliferation and cytokine production $(2,3)$ and might influence the immunemediated destruction of insulin-producing $\beta$-cells of the pancreas. Moreover, vitamin D deficiency leads to impaired insulin secretion, which is reversible by 1,25-dihydroxyvitamin D3 administration. This process has been described in human and other animal studies (4-6). The pleiotropic biological actions of vitamin D are mediated by the vitamin D receptor (VDR) $(7,8)$. The importance of vitamin $\mathrm{D}$ is further supported by the finding that pancreatic $\beta$-cells express VDR (9).

The function of the VDR gene is influenced by several genetic polymorphisms. The schematic structure of the VDR gene and the localization of restriction sites are presented in Fig. 1. The polymorphic FokI site in exon 2 results in an alternative transcription initiation site, leading to the addition of three amino acids to the VDR protein in individuals with the 'f' allele (10). BsmI ('b'), ApaI ('a') and Tru9I ('u') sites are in introns, but alterations in intronic sequence may influence protein expression. A silent $\mathrm{T}$ to $\mathrm{C}$ substitution at position 1055 in exon 9 creates the TaqI restriction site (the ' $t$ ' allele) $(11,12)$. According to specific data, VDR polymorphisms are associated with plasma calcitriol levels (13), parathyroid calcium response and calcium sensor protein (14-16), and urinary calcium excretion (17). Polymorphisms do have an impact on hyperparathyroidism $(13,14,18,19)$, Graves' disease (20), bone mass and turnover $(12,21)$, primary biliary cirrhosis (22), oncogene expression and rectal cancer prognosis (23).

The effects of VDR polymorphisms on insulin secretion have been reported (24). Correlation between the BsmI polymorphism and type 2 diabetes (T2DM) 


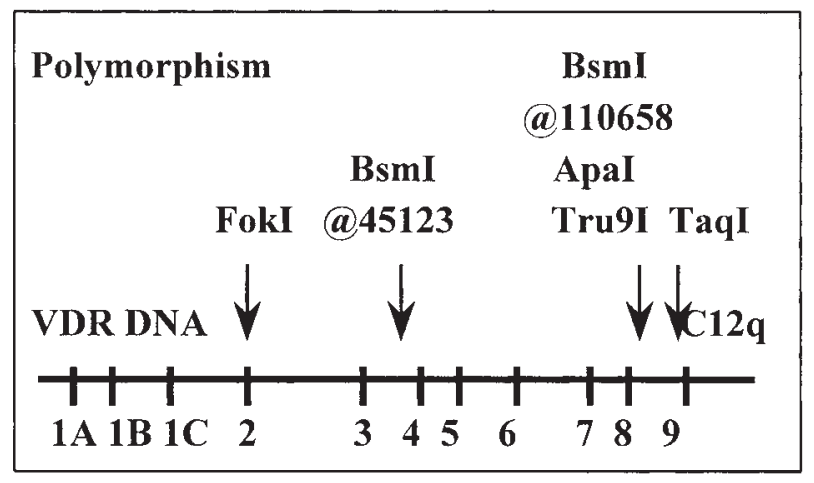

Figure 1 Schematic structure of the human VDR gene. The exons are indicated by numbers. The positions of the restriction sites investigated are also shown (11, 12, 18, 29-32).

has also been documented (25). Other studies observed no correlation between T2DM and BsmI, TaqI, ApaI and Tru9I polymorphisms of the VDR gene (26). Combinations of VDR BsmI, ApaI and TaqI polymorphisms increased the susceptibility to T1DM in Germans (11) and in Indian Asians (27). However, no data are available about the Tru9I polymorphism in T1DM.

We have investigated the prevalence of each known VDR polymorphism as well as their association with clinical characteristics in children with T1DM.

\section{Patients and methods}

\section{Patients}

One hundred and seven unrelated Caucasian children with T1DM attending the First Department of Paediatrics, Semmelweis University, Budapest, Hungary, were enrolled on the study. The diagnosis of T1DM was established at least 5 years prior to the investigation. The boy to girl ratio of T1DM probands was 57/50. To characterize our diabetic population, we recorded age at the onset of diabetes, body mass index (BMI), microalbuminuria and serum haemoglobin $A_{\text {Ic }}\left(\mathrm{HbA}_{\mathrm{Ic}}\right)$. All patients with diabetes were islet cell autoantibodies (ICA) positive $(10<$ juvenile diabetes foundation units (JDFU)). Age at the onset of diabetes was between 1 and 14 years in the diabetic group, with an average of $5.8 \pm$ 3.2 years. The average BMI of all patients was $17.0 \pm$ $2.3 \mathrm{~kg} / \mathrm{m}^{2}$. BMI values were related to the age-matched percentile values. Each child's BMI was within the 2575 percentile interval. Microalbuminuria was present in $34 \%$ of patients, the serum $\mathrm{HbA}_{\text {Ic }}$ level was $7.87 \pm$ 1.05. No differences were detected between boys and girls.

Reference values for the prevalence of each genetic variant were obtained from 103 healthy blood donors ( 53 men and 50 women). The advantage of this population is the extremely low risk of development of T1DM. They were not screened for ICA autoantibodies.
However, each donor filled out a detailed questionnaire concerning health risk factors before blood donation and none of them indicated the presence of T1DM in first-degree relatives. They were all from Budapest, as were the diabetic patients.

At the beginning of sample collection the informed consent of parents was obtained for the use of samples from their children for diagnostic and scientific purposes. At the beginning of data processing all samples received a unique three digit number, and during further analyses this number was used without referring to the patient's name. An independent institutional ethical committee approved the study.

\section{DNA isolation}

Blood was collected in EDTA $-\mathrm{K}_{3}$ tubes and stored at $-20^{\circ} \mathrm{C}$ until DNA extraction. DNA was purified by standard proteinase $\mathrm{K}$ digestion, phenol-chloroform extraction and ethanol precipitation (28).

\section{Genotyping}

DNA was amplified with a standard PCR technique. After initial denaturation for $4 \mathrm{~min}$ at $94^{\circ} \mathrm{C}$, samples were subjected to 35 cycles of amplification, consisting of a 30-s denaturating phase at $94^{\circ} \mathrm{C}$, a 30-s annealing phase (see temperature below) and a 30-s extension phase at $72^{\circ} \mathrm{C}$. A 4 -min $72^{\circ} \mathrm{C}$ hold was the final step of the programme. After restriction, the end products were electrophoresed on a $2 \%$ agarose gel containing $0.4 \mathrm{mg} / \mathrm{l}$ ethidium bromide. The polymorphism was documented by photographing under UV illumination. We used an internal control for verification of complete digestion. A random subset ( $\sim 10 \%$ of samples) was repeatedly measured to verify the results. Upper case letters indicate the absence of the cut site, whereas lower case letters indicate its presence. Letters for the alleles are the first letters of the restriction enzyme, except for Tru9I, where ' $u$ ' is used.

\section{FokI polymorphism}

The sense primer: 5-AGC TGG CCC TGG CAC TGA CTC TGC TCT-3, and the reverse primer: 5-ATG GAA ACA CCT TGC TTC TTC TCC CTC-3 (29) were used at an annealing temperature of $60^{\circ} \mathrm{C}$. Five units of FokI restriction enzyme (Promega Corp., Madison, WI, USA) and $1.5 \mu \mathrm{l}$ buffers were added to $10 \mu \mathrm{l}$ of the PCR product. The overnight restriction was at $37^{\circ} \mathrm{C}$ according to the supplier's recommendation. The FokI alleles are designated ' $\mathrm{F}$ ' and ' $\mathrm{f}$ '.

The amplified sequence starts at position 11963 in Genbank (http://www.ncbi.nlm.nih.gov/entrez/query. fcgi?db=nucleotide) accession no. AC004466 (30), the amplified fragment is $265 \mathrm{bp}$ in length. The restriction enzyme for FokI polymorphism binds at position $12019\left(\operatorname{GGATG}(\mathrm{N}) 9^{\wedge}\right)$. 


\section{ApaI and TaqI polymorphisms}

For the detection of ApaI and TaqI polymorphisms the sense primer: 5-CAG AGC ATG GAC AGG GAG CAA-3 and the reverse primer: 5-GCA ACT CCT CAT GGC TGA GGT CTC-3 were used at an annealing temperature of $70^{\circ} \mathrm{C}$ (31). The digestion with ApaI $\left(\right.$ GGGCC $^{\wedge} \mathrm{C}$; F Hoffmann-La Roche Inc., Nutley, NJ, USA) was performed with $10 \mathrm{U}$ enzyme and $10 \mu \mathrm{l}$ PCR product at $30^{\circ} \mathrm{C}$ for $4 \mathrm{~h}$. The ApaI alleles are designated 'A' and ' $a$ '. From the enzyme TaqI ( $\mathrm{T}^{\wedge} \mathrm{CGA}$; MBI Fermentas Inc., St Leon-Rot, Germany) $3 \mathrm{U}$ was added to the amplified mixture, and digestion was at $65^{\circ} \mathrm{C}$ for $4 \mathrm{~h}$. The TaqI alleles are designated ' $\mathrm{T}$ ' and ' $\mathrm{t}$ '.

The $740 \mathrm{bp}$ length amplified sequence starts at position 111403 and ends at position 112143 in Genbank accession no. AC004466. After digestion with ApaI, a $530 \mathrm{bp}$ and a $210 \mathrm{bp}$ length fragment can be detected. TaqI has two binding sites on the PCR product, one produces a $495 \mathrm{bp}$ and a $245 \mathrm{bp}$ fragment, and the other is at the single nucleotide polymorphism site in the presence of which the $495 \mathrm{bp}$ fragment will be cut into a smaller $290 \mathrm{bp}$ piece and a $205 \mathrm{bp}$ piece.

\section{BsmI polymorphism}

The sense primer: 5-AGT GTG CAG GCG ATT CGT AG-3 and the reverse primer: 5-ATA GGC AGA ACC ATC TCT CAG-3 were used at an annealing temperature of $62^{\circ} \mathrm{C}$. For the restriction, $5 \mathrm{U}$ of the BsmI enzyme (GAATGCN $^{\wedge}$; Qbiogene Inc., Heidelberg, Germany) was used at $65^{\circ} \mathrm{C}$ for $4 \mathrm{~h}(18)$. The BsmI alleles are designated 'B' and 'b'.

The amplified sequence is between positions $45007-$ 45198 and 110 543-110 734 in Genbank accession no. AC004466, the amplified fragment is $191 \mathrm{bp}$ in length and after successful digestion a $115 \mathrm{bp}$ and a 76 bp line can be seen. One of the BsmI cut sites $\left(\mathrm{GAACTGgg}^{\wedge}\right)$ is at 45123 , the other at 110658 .

\section{Tru9I polymorphism}

The sense primer: 5-TGA GGT TTC TTG CGG GCA GGG TA-3 and the reverse primer: 5-CAG GGC CGC CCC TCT TTG GA-3 were used at an annealing temperature of $72^{\circ} \mathrm{C}$. Five units of the Tru9I enzyme (Promega Corp.) digested the PCR product for $4 \mathrm{~h}$ at $65^{\circ} \mathrm{C}$. We designed primers using the Primer 3 software (http:// www-genome.wi.mit.edu/genome_software/other/ primer3.html) on the VDR Genbank sequence AC004466 $(30,32)$. The amplified sequence starts at position 90260 in Genbank accession no. AC004466, the amplified fragment is $212 \mathrm{bp}$ in length. The Tru9I alleles are designated ' $U$ ' and ' $u$ '.

\section{Statistical analyses}

Hardy-Weinberg equilibrium was calculated to evaluate the relationship between gene frequencies and genotype frequencies. Chi-square tests and Fisher's exact test were used to compare prevalence of genetic polymorphisms in T1DM and in controls. Odds ratios were computed when data were significantly different. For linkage and distribution calculations the Arlequin software (http://anthropologie.unige.ch/arlequin/) was used. The level of statistical significance was set at $P<0.05$.

\section{Results}

The prevalence of the 'f', 'b', 'a' and ' $u$ ' alleles are in the Hardy-Weinberg equilibrium. The ' $\mathrm{t}$ ' and ' $\mathrm{T}$ ' alleles miss the Hardy-Weinberg equilibrium $(P<0.0001)$. Based on these results we excluded the TaqI polymorphism from further analysis (see Table 1).

The prevalence of ' $\mathrm{f}$ ', ' $b$ ' and 'a' alleles did not differ between boys and girls, either in T1DM or control subjects. The homozygous genotype 'uu' was not present in T1DM and controls. Clinical characteristics and VDR alleles were not associated.

The alleles 'b' and 'a', 'b' and ' $u$ ' were in linkage disequilibrium in control and T1DM subjects. The alleles 'a' and ' $u$ ' were in linkage disequilibrium only in controls (See Table 2). The 'f' allele was not associated with any of the other alleles.

The prevalence of studied polymorphisms did not differ between healthy and diabetic subjects (see Table 1).

Table 1 Prevalence of VDR gene polymorphisms and alleles in control and diabetic subjects.

\begin{tabular}{|c|c|c|c|c|}
\hline & Control & Allele & Diabetic & Allele \\
\hline \multicolumn{5}{|l|}{ Fokl } \\
\hline FF & 0.33 & & 0.28 & \\
\hline $\mathrm{Ff}$ & 0.46 & & 0.55 & \\
\hline $\mathrm{ff}$ & 0.20 & 'f' $=0.43$ & 0.17 & 'f' $=0.44$ \\
\hline \multicolumn{5}{|l|}{ Bsml } \\
\hline BB & 0.16 & & 0.18 & \\
\hline $\mathrm{Bb}$ & 0.50 & & 0.43 & \\
\hline $\mathrm{bb}$ & 0.33 & 'b' $=0.58$ & 0.39 & 'b' $=0.60$ \\
\hline \multicolumn{5}{|l|}{ Taql } \\
\hline TT & 0.41 & & 0.41 & \\
\hline $\mathrm{Tt}$ & 0.26 & & 0.32 & \\
\hline $\mathrm{tt}$ & 0.31 & $' \mathrm{t} '=0.45$ & 0.25 & $' \mathrm{t} '=0.41$ \\
\hline \multicolumn{5}{|l|}{ Apal } \\
\hline $\mathrm{AA}$ & 0.31 & & 0.22 & \\
\hline $\mathrm{Aa}$ & 0.42 & & 0.52 & \\
\hline aa & 0.25 & 'a' $=0.46$ & 0.25 & ' $a$ ' $=0.51$ \\
\hline \multicolumn{5}{|l|}{ Tru9l } \\
\hline UU & 0.81 & & 0.78 & \\
\hline Uu & 0.18 & & 0.21 & \\
\hline uu & 0 & 'u' $=0.09$ & 0 & ' $u^{\prime}=0.10$ \\
\hline
\end{tabular}

The polymorphisms Fokl, Bsml, Apal and Tru9l ('f', 'b', 'a' and 'u' respectively) are in Hardy-Weinberg equilibrium. The difference between the expected and measured distributions at the Taql (' $\mathrm{t}$ ') polymorphism are significant $(P<0.0001)$. 
Table 2 Linkage disequilibrium values between the restriction sites Bsml, Apal and Tru9l ('b', 'a' and 'u' respectively) in control and diabetic subjects.

\begin{tabular}{|c|c|c|c|}
\hline & $\mathbf{D}^{\prime}$ & Chi-square & $P$ \\
\hline \multicolumn{4}{|l|}{ Control } \\
\hline 'b' × 'a' & 0.86 & 23.12 & $<0.001$ \\
\hline 'b' × ‘u' & -0.75 & 5.04 & $<0.05$ \\
\hline 'a' x ‘u' & 0.60 & 7.39 & $<0.01$ \\
\hline \multicolumn{4}{|l|}{ Diabetic } \\
\hline 'b' × 'a' & 0.78 & 44.04 & $<0.001$ \\
\hline 'b' × 'u' & -0.76 & 4.14 & $<0.05$ \\
\hline 'a' x ‘u' & 0.12 & 1.36 & n.s. \\
\hline
\end{tabular}

Correlation with the 'f' allele was not observed. $D$ ', standardized disequilibrium values; n.s., not significant.

No single allele was associated with T1DM. However, the prevalence of ' $\mathrm{Uu}$ ' was higher in girls with T1DM compared with control subjects (girls/boys: control 7/18 vs T1DM 16/5; $P<0.01$ ).

The number of girls carrying the alleles 'b', 'a' and ' $u$ ' simultaneously was higher in T1DM than in controls ('b' + 'a' + 'u' present/absent: diabetic' 13/37; healthy, 0/53; $P<0.005)$. The clinical characteristics and age at the onset of T1DM did not differ between T1DM girls with or without 'b' + 'a' + 'u'. In boys such a phenomenon was not present $(' b$ ' + 'a' + 'u' present/missing: healthy, 1/52; diabetic, 1/56; not significant) (see Table 3).

\section{Discussion}

The prevalence of 'f', 'b', 'a' and ' $u$ ' alleles in healthy controls was similar to data reported previously in Japanese (29) and Caucasian populations (18, 32). The prevalences were similar to those in our T1DM patients and control subjects.

Our measured ' $\mathrm{t}$ ' allele frequencies were different from those found by Ongphiphadhanakul et al. (17) in Thailand. However, the distributions of the ' $t$ ' and

Table 3 Prevalence of haplotypes in control and diabetic subjects: the presence of polymorphisms Bsml, Apal and Tru9l ('b', 'a' and 'u' respectively).

\begin{tabular}{lcccc}
\hline & \multicolumn{2}{c}{ Control } & & \multicolumn{2}{c}{ T1DM } \\
\cline { 2 - 3 } & $\mathrm{U}$ & $\mathrm{u}$ & $\mathrm{U}$ & $\mathrm{u}$ \\
\hline Males & & & & \\
$\mathrm{BA}$ & 0.16 & - & 0.17 & 0.02 \\
$\mathrm{Ba}$ & 0.02 & - & 0.05 & - \\
bA & 0.02 & 0.10 & - & 0.07 \\
ba & 0.66 & 0.02 & 0.67 & 0.02 \\
Females & & - & & \\
$\mathrm{BA}$ & 0.25 & - & 0.16 & - \\
$\mathrm{Ba}$ & - & - & 0.02 & - \\
bA & - & 0.06 & - & 0.07 \\
ba & 0.69 & - & 0.47 & $0.29^{*}$ \\
\hline * $P<0.01$ & compared with & & &
\end{tabular}

www.eje.org
'T' alleles were not in Hardy-Weinberg equilibrium. Therefore, the association between the ' $t$ ' allele and T1DM was not analyzed in our study. One can speculate why the Hardy-Weinberg criteria are not fulfilled in a healthy population. The Hungarian population's unique genetic background might be one of the possible explanations (33).

Previous studies reported linkage between the alleles 'a', 'b' and ' $\mathrm{t}$ ' $(34,35)$. Uitterlinden et al. (35) found that, after constructing molecular haplotypes across this area of the VDR gene, the most frequent haplotypes in Caucasians are 'baT' (50\%), 'Bat' $(40 \%)$ and 'bAT' $(10 \%)$. They also suggested that the variation of the degree of linkage disequilibrium between restriction fragment length polymorphism loci in the studied population might influence the degree of association between alleles and characteristics (36). Although we could not analyse the ' $\mathrm{t}$ ' allele, we have detected a strong linkage disequilibrium between the 'b', ' $a$ ' and ' $u$ ' alleles. This suggests that their inheritance is not independent in our study population. The close location of these polymorphisms might be an explanation for the stability of this linkage, but the background of these combinations will need further investigation. The linkage between the ' $b$ ' and the other alleles suggests that these polymorphisms could possibly be responsible for the clinical associations previously associated with BsmI but where other polymorphisms were not associated $(11,25,27)$.

Pani et al. (11) reported an increased susceptibility to T1DM in Germans with combinations of VDR polymorphisms. In their study, the 'At', 'Bt' and 'BAt' alleles presented an increased risk, whereas 'AT' and 'at' were protective. Since we could not analyze the effect of ' $t$ ' alleles in our population, we cannot confirm or reject their observations.

During our study we found a strong association between the carrier state of the 'b' + 'a' + 'u' alleles and the presence of T1DM in girls. Our results suggest that this allele combination presents an important risk for T1DM, although it does not influence the other clinical parameters of T1DM studied. This novel finding suggests a gender-specific difference. Other publications also report association between gender and the consequences of gene polymorphisms (37). Polymorphism in the hormone-sensitive lipase is associated with markers of insulin sensitivity in women but not in men (38) and VDR polymorphisms are associated with sex-dependent growth (39). However, the significance of this finding is hard to appreciate since the disease generally affects males and females equally, raising the question as to whether this finding is related to a specific feature of the selected Hungarian population rather than a true association with the disease. Confirmation of the association with other genetic approaches, for example using family studies, would provide more convincing evidence. 
Evaluation of our data is further complicated by the fact that there are two restriction sites for BsmI ('b') in the VDR gene. Studying the Genbank sequence we noticed that a large DNA sequence - containing the BsmI restriction site and both sense and reverse primer binding sites - is present in a repetitive area twice in the VDR gene. The lengths of the amplified sequences are identical and, using our method, it cannot therefore be decided whether there are one or two BsmI restriction sites in heterozygous individuals. This characteristic of the VDR gene has not been mentioned in the interpretation of previous data $(11,13$, $18,22,23)$. Further investigation is needed to clarify whether only one or both of the two ' $b$ ' alleles are present in diabetic 'b' + ' $a$ ' + ' $u$ '-positive girls who are heterozygous for the ' $\mathrm{Bb}$ ' alleles.

Our report is the first one to collect data for frequencies of all five known restriction sites of the VDR gene in healthy and T1DM Caucasian populations. Our results suggest that the common presence of the cut sites for the BsmI, ApaI and Tru9I polymorphism of the VDR gene in the Hungarian population greatly increases the probability of T1DM in girls but not in boys. These results should also be evaluated for other ethnic groups.

\section{Acknowledgements}

This work was supported by Hungarian research grants FKFP 0606/2000, ETT 32/2000 and OTKA T037578F032024.

\section{References}

1 Hyppönen E, Läärä E, Reunanen A, Järvelin M-R \& Virtanen SM. Intake of vitamin $\mathrm{D}$ and risk of type 1 diabetes: a birth-cohort study Lancet 2001358 1500-1503.

2 Thomasset M. Vitamin D and the immune system. Pathologie Biologie 199442 163-172.

3 Saggese G, Frederico G, Balestri M \& Torriolo A. Calcitriol inhibits the PHA-induced production of IL-2 and IFN-gamma and the proliferation of human peripheral blood leukocytes while enhancing the surface expression of HLA class II molecules. Journal of Endocrinological Investigation $198912329-335$.

4 Norman AW, Frankel BJ, Helt AM \& Grodsky GM. Vitamin D deficiency inhibits pancreatic secretion of insulin. Science 1980 $209823-825$.

5 Boucher BJ. Mannan N, Noonan K. Hales CN \& Evans SJ. Glucose intolerance and impairment of insulin secretion in relation to vitamin D deficiency in East London Asians. Diabetologia 1995 38 1239-1245.

6 Bourlon PM, Faure-Dussert A, Billaudel B, Sutter BC, Tramu G \& Thomasset M. Relationship between Calbindin-D28K levels in the $A$ and $B$ cells of the rat endocrine pancreas and the secretion of insulin and glucagon: influence of vitamin D3 deficiency and 1,25-dihydroxyvitamin D3. Journal of Endocrinology $1996 \mathbf{1 4 8}$ $223-232$

7 Pike JW. Vitamin D3 receptors: structure and function in transcription. Annual Review of Nutrition 199111 189-216.

8 Christakos S, Raval-Pandya M, Wernyj RP \& Yang W. Genomic mechanisms involved in the pleiotropic actions of 1,25-dihydroxyvitamin D3. Biochemical Journal 1996316 361-371.
9 Lee S, Clark SA, Gill RK \& Christakos S. 1,25-Dihydroxyvitamin D3 and pancreatic $\beta$-cell function: vitamin D receptors, gene expression and insulin secretion. Endocrinology $1994 \mathbf{1 3 4}$ $1602-1610$.

10 Miyamoto K, Kesterson RA, Yamamoto H, Taketani Y, Nishiwaki E, Tatsumi S et al. Structural organization of the human vitamin D receptor chromosomal gene and its promoter. Molecular Endocrinology 199711 1165-1179.

11 Pani MA, Knapp M, Donner H, Braun J, Baur MP, Usadel KH et al. Vitamin D receptor allele combinations influence genetic susceptibility to type 1 diabetes in Germans. Diabetes $2000 \mathbf{4 9}$ $504-507$.

12 Langdahl BL, Gravholt CH, Brixen K \& Eriksen EF. Polymorphisms in the vitamin D receptor gene and bone mass, bone turnover and osteoporotic fractures. European Journal of Clinical Investigation $200030608-617$

13 Paz Marco M, Martínez I, Amodeo ML, Borrás M, Saracho R, Almirall J et al. Vitamin D receptor genotype influences parathyroid hormone and calcitriol levels in predialysis patients. Kidney International 199956 1349-1353.

14 Carling T, Ridefelt P, Hellman P, Juhlin C, Lundgren E, Akerström $\mathrm{G}$ et al. Vitamin D receptor gene polymorphism and parathyroid calcium sensor protein (CAS/gp330) expression in primary hyperparathyroidism. World Journal of Surgery 199822 700-707.

15 Yokohama K, Shigematsu T, Kagami S, Tsukada T, Arai T, Hara S et al. Vitamin $\mathrm{D}$ receptor gene polymorphism detected by digestion with ApaI influences the parathyroid response to extracellular calcium in Japanese chronic dialysis patients. Nephron 200189 315-320.

16 Carling T, Rastad J, Akerstrom G \& Westin G. Vitamin D receptor (VDR) and parathyroid hormone messenger ribonucleic acid levels correspond to polymorphic VDR alleles in human parathyroid tumors. Journal of Clinical Endocrinology and Metabolism 1998 $832255-2259$.

17 Ongphiphadhanakul B, Rajatanavin R, Chanpraserthyothin S, Chailurkit L, Piaseu N, Teerarungsikul K et al. Vitamin D receptor gene polymorphism is associated with urinary calcium excretion but not with bone mineral density in postmenopausal women. Journal of Endocrinological Investigation $199720592-596$.

18 Sosa M, Torres A, Martin N, Salido E, Liminana JM, Barrios Y et al. The distribution of two different vitamin D receptor polymorphisms (BsmI and start codon) in primary hyperparathyroidism. Journal of Internal Medicine 2000247 124-130.

19 Carling T, Ridefelt P, Hellman P, Rastad J \& Akerstrom G. Vitamin $D$ receptor polymorphisms correlate to parathyroid cell function in primary hyperparathyroidism. Journal of Clinical Endocrinology and Metabolism 199782 1772-1775.

20 Ban Y, Taniyama M \& Ban Y. Vitamin D receptor gene polymorphism is associated with Graves' disease in the Japanese population. Journal of Clinical Endocrinology and Metabolism $2000 \mathbf{8 5}$ 4639-4643.

21 Ferrari S, Manen D, Bonjour JP, Slosman D \& Rizzoli R. Bone mineral mass and calcium and phosphate metabolism in young men: relationships with vitamin D receptor allelic polymorphisms. Journal of Clinical Endocrinology and Metabolism $1999 \mathbf{8 4}$ 2043-2048.

22 Halmos B, Szalay F, Cserniczky T, Nemesanszky E, Lakatos P, Barlage $S$ et al. Association of primary biliary cirrhosis with vitamin $\mathrm{D}$ receptor Bsm1 genotype polymorphism in a Hungarian population. Digestive Diseases and Sciences 200045 1091-1095.

23 Speer G, Dworak O, Cseh K, Bori Z, Salamon D, Török I et al. Vitamin D receptor gene BsmI polymorphism correlates with erbB2/HER-2 expression in human rectal cancer. Oncology $2000 \mathbf{5 8}$ $242-247$.

24 Hitman GA, Mannan N, McDermott ME, Aganna E, Ogunkolade $\mathrm{BW}$, Hales CN et al. Vitamin D receptor gene polymorphisms influence insulin secretion in Bangladeshi Asians. Diabetes 199847 688-690.

25 Speer G, Cseh K, Winkler G, Vargha P, Braun E, Takacs I et al. Vitamin D and estrogen receptor gene polymorphisms in type 2 
diabetes mellitus and in android type obesity. European Journal of Endocrinology $2001 \mathbf{1 4 4}$ 385-389.

26 Wei-Zhen Y, Reis AF, Dubois-Laforgue D, Bellanné-Chantelot C, Timsit J \& Velho G. Vitamin D receptor gene polymorphisms are associated with obesity in type 2 diabetic subjects with early age of onset. European Journal of Endocrinology $2001 \mathbf{1 4 5}$ $181-186$.

27 McDermott MF, Ramachendran A, Ogunkolade BW, Aganna E, Curtis D, Boucher BJ et al. Allelic variations in the vitamin D receptor influences susceptibility to IDDM in Indian Asians. Diabetologia $1997 \mathbf{4 0} 971-975$.

28 Miller SA, Dykes DD \& Polesky HF. A simple salting out procedure for extracting DNA from human nucleated cells. Nucleic Acids Research 1988161215.

29 Minamitani K, Takahashi Y, Minagawa M, Yasuda T \& Niimi H. Difference in height associated with a translation start site polymorphism in the vitamin D receptor gene. Pediatric Research $198844628-632$.

30 Muzny D, Arenson AD, Adams C, Bunac C, Carvelli K, Chang J et al. VDR gene. Genbank accession no. AC004466.

31 Riggs BL, Nguyen TV, Melton LJM, Morrison NA, O’Fallon WM, Kelly PJ et al. The contribution of vitamin D receptor gene alleles to the determination of bone mineral density in normal and osteoporotic women. Journal of Bone and Mineral Research $1995 \mathbf{1 0}$ 991-996.

32 Wei-Zhen Y, Fernandes Reis A \& Velho G. Identification of a novel Tru9I polymorphism in the human vitamin D receptor gene. Journal of Human Genetics 200045 56-57.

33 Hermann R, Mijovic CH, Rayner M, Croft N, Kelly MA, Jenkins D et al. HLA alleles and IDDM in children in Hungary: a comparison with Finland. Human Immunology 200162 391-398.
34 Morrison NA, Qi JC, Tokita A, Kelly PJ, Crofts L, Nguyen TV et al. Prediction of bone density from vitamin D receptor alleles. Nature 1994367 284-287.

35 Uitterlinden AG, Pols HA, Burger H, Huang Q, Van Daele PL, Van Duijn C et al. A large-scale population-based study of the association of vitamin $\mathrm{D}$ receptor gene polymorphism with bone mineral density. Journal of Bone and Mineral Research 199611 1241-1248.

36 Peltekova VD, Rubin L, Uitterlinden AG, Hawker G, Vieth R, Trang $\mathrm{H}$ et al. Direct hapoltyping at the vitamin D receptor locus improves genetic resolution. Journal of Bone and Mineral Research $199712494-495$.

37 Kitagawa I, Kitagawa Y, Kawase Y, Nagaya T \& Tokudome S. Advanced onset of menarche and higher bone mineral density depending on vitamin D receptor gene polymorphism. European Journal of Endocrinology $1998139522-527$.

38 Talmud PJ, Palmen J, Luan J, Flavell D, Byrne CD, Waterworth DM et al. Variation in the promoter of the human hormone sensitive lipase gene shows gender specific effects on insulin and lipid levels: results from the Ely study. Biochimica et Biophysica Acta $20011537239-244$.

39 Suarez F, Zeghoud F, Rossignol C, Walrant O \& Garabedian M. Association between vitamin D receptor gene polymorphism and sex-dependent growth during the first two years of life. Journal of Clinical Endocrinology and Metabolism 199782 2966-2970.

Received 14 May 2002

Accepted 3 September 2002 